\title{
Some Reflections on a Research Journey in Law and Society
}

By Martin Chanock (Emeritus Professor at the School of Law, La Trobe University, Melbourne, Australia)

La Trobe University, Melbourne, Australia

\section{ABSTRACT}

A research journey is not planned but develops according to where one is geographically, and the politics of the broader world, and of scholarship, at the time. My journey took me from South Africa, through England, to Africa in the period after decolonisation, and finally to an inter-disciplinary School at La Trobe University. My research, with its foci on colonialism, and a post-colonial world that continues to be dominated by the Global North, reflects this.

Keywords - History, Law, Colonialism, Custom, Anthropology, Constitutionalism

Disclosure statement - No potential conflict of interest was reported by the author.

License - This work is under Attribution-NonCommercial-ShareAlike 4.0 International (CC BY-NC-SA 4.0) https://creativecommons.org/licenses/by-nc-sa/4.0/

Suggested citation: Chanock, M. 2019. "Some reflections on a research journey in law and society." Law in Context, 36 (1): 21-28. DOI: https://doi.org/10.26826/ law-in-context.v36i1.83.

\section{Summary}

1. Studying Law and History in South Africa

2. Graduate studies and Africa

3. Social Anthropology

4. African Customary Law and the Nation State

5. African Constitutionalism

\section{STUDYING LAW AND HISTORY IN SOUTH AFRICA}

The editors asked me to write about my research journey. The idea of the journey implies that one knows where one is going, but my journey was a series of accidents. My primary "disciplinary" orientation is History. I did not set out to study history as an undergraduate but did so in order to get a lift to campus rather than a journey involving the bus and a long walk. But I soon found that it was more satisfactory intellectually than any other offerings in the social sciences. They all seemed to me, to use A. J. P. Taylor's description of Sociology, to be "history with the history left out". I was an undergraduate in Johannesburg during the years in which the University of the Witwatersrand was closed to non-white students, and in which major oppressive pieces of apartheid legislation were passed; so campus life was intensely political. My first experience of the campus was being tear gassed; so, the study of everything was political. As a radical(ised?) undergraduate I demanded (echoes of current South 
African students demanding decolonisation of the curriculum) that we should be taught "radical history", of the Professor J. S. Marais. His reply was simple: "The truth itself is radical". A better response cannot be imagined. It serves as the starting point for any research journey. This still seems to me to be obvious even in a "post truth" era in which radicalism has splintered into various forms of subjectivity. Our Professor was much attached to the ideas of Wilhem Dilthey-a subjective approach to the understandings of the minds of the persons one studied concerning the things that they did. Overarching this, and conflicting with it, was the pervasive Marxism of the struggles of the left in South Africa. Armed both with the mysteries of German verstehen and Marxist materialism I set out on my academic journey. ${ }^{1}$ My first piece of research, an honours dissertation, traced part of the history of the white Labour Party in South Africa, a curious assembly which championed both conventional socialism, and the exclusive rights of white workers.

After my undergraduate degree I began an LLB which was also a professional qualification for the Bar in South Africa. The law we were taught was deliberately a-political. This was profoundly objectionable to me. I also found it boring (with the exception of the course in legal history which everyone else hated). But in retrospect, the degree was very valuable to me. Most importantly, it taught me to read slowly and carefully. Secondly it taught me to pay as close attention to the other side of any argument, as I did to my own. And thirdly, a legal education in South Africa could not describe an intellectually closed system of rules because South Africa had a mixed legal heritage of Roman civil, and English common law. So, there was never the possibility of thinking about just one way of doing law, which is a mindset that cripples most legal education. ${ }^{2}$ And, as anyone who has had a legal education knows, the study of law, with its powerful and logical categories and characterisations, structures the way in which one sees the world. It is hard to escape from, and has no doubt influenced my approach to the social sciences. I also spent enough time as an articled clerk in solicitors' practices to discover that it was not what I wanted to do with my life.

\section{GRADUATE STUDIES AND AFRICA}

My political life made it necessary for me to leave South Africa. But I might have done so anyway in that any Anglo-colonial would-be intellectual then thought of Oxford or Cambridge as their natural destination in life. I was rewarded for my politics with a scholarship to Cambridge. I certainly did not want to study law again. I opted for a post graduate research degree in History. But what history? I thought of the English Civil War and the New Model Army, an obvious dream world for a radical South African. But then I thought of what I wanted to do once I had finished. This was 1965. The decolonisation of Africa to the North of South Africa was virtually complete. I was clear that I wanted to work in the new Africa. This pointed towards an African topic-one centred in the experiences of colonialism. I had often fantasised about writing a "History of British Imperial Crimes" in several volumes, so this explains my orientation. But my first choice was to go for the obvious centre of Africa's darkest experience - the Belgian Congo. ${ }^{3}$ I spent close to a year working on the horrors of the holocaustal Congolese experience and the reactions to these in Europe only to discover that someone else had just submitted a thesis with themes close to my own. So, I had just over two years to find and finish something else. The topic most current in contemporary Africa was then the white Rhodesian declaration of independence. So, I decided to write an account of how they came to be in this position of power. From this dissertation I published my first book. ${ }^{4}$ It had very little to do with law.

\footnotetext{
${ }^{1}$ Verstehen has lost its easy grip as a working method in a "postmodern" world in which readers have become authors and we look for absences as well as presences, suppressions and choices of representation. Marxists have dwindled. The challenge of relating individuals and structures remains. Both positivism and functionalism, the major cores of "social science", (and ultimately law and society studies), were absent from my subsequent innate approaches.

${ }^{2}$ And, as I was to discover as a socio-legal scholar, in an environment in which scholars became globally mobile, it hampered understanding. Very many scholars were, and are, in the habit of referring to "Law", but some have a common law referent, and some a civil law referent. But these are very different.

${ }^{3}$ Cambridge had specified facility in two African languages. Its colonial mindset accepted both French and Afrikaans, perfect for working on documents related to the Belgian Congo in Flemish and French.

${ }^{4}$ Martin Chanock, 1977. Unconsummated Union. Britain, Rhodesia and South Africa 1900-1945, Manchester: Manchester University Press. It gives an account of the British attempt to build a white settler-dominated dominion in East and Central Africa as an imperial counterweight to Afrikaner South Africa.
} 
So, what to do next? I would not go back to South Africa. I wanted to work in a newly independent African state. I was offered a job at the University of Malawi, a country much criticised for its political links with the apartheid regime. To me, however, it seemed ideal. The faculty had remarkable young scholars and a strong research orientation in an intellectual climate which strongly felt that the history of this new country needed writing. But how? I wanted to understand not events, but the experiences of colonialism. How could one find this where there was so little in the way of written sources and the people about whom I wanted to write had died? The British colonial regime had kept copious records of its own doings, but they were largely about how to govern people, and less about what they felt. I was drawn towards what I thought of as the cutting edge of colonialism-its courts and means of enforcement-as it was here that I hoped to find the most emotive parts of the confrontations between rulers and ruled. What I found was that these were the arenas in which African subjects were able to speak. They turned out to be able to express their views about the colonial dispensation, and, as it turned out, this was the only arena through which they could influence colonial governments.

Colonial governments wanted to enforce Africans' own "customary laws". But who could tell them what these were, if not Africans? So African interlocutors could, and did, devise versions of customary law that suited particular interests - those of men and elders. As a particularly brutal form of capitalist change was restructuring the lives of Africans under colonial rule, their own social relationships were being wrenched into new forms. Relationships between genders and generations, which were at the core of the "customary law", were undergoing profound changes. Intense arguments about these found their way into the courts. It became very clear that "customary law" was no longer (if it ever had been) something handed down in pristine form from an immemorial past. It was clearly something being constantly remade, in reflection of profound social conflicts, even though it made use of the same traditional language and symbols. To my surprise the usable materials for the study turned out to be archival. Laboriously acquired oral data had to be discarded as it clearly reflected the present and not the past, which is just what my thesis about the continuing creation of custom would have led one to expect.

The archives led me to needing to change the ruling idea of what customary law was, and this led inevitably to a need to review the ways in which law in Africa (and law in colonial situations) had been conceived. This turned the book from one just focussing on the colonial experience, to being a book about law. ${ }^{5}$

This was a book I felt confident to write given that no-one writing African history had a legal background. There was little understanding of what law was, or how it worked. Law was seen as being a body of "rules", which were applied by courts to settle disputes. Above all, law was about authority. The ideas that rules were regularly indeterminate; that they were "interpreted", often ideologically; and that few disputes found their ways to court but were "settled" by cultural norms; were not part of lay knowledge. Colonial lawyers wrote a great deal about African law as it was crucial to their governing agenda. Their framework was evolutionist. African law, like Africans, was primitive. While it could be taught to evolve over a long time period, it was quite different from civilised law. The main feature of the difference was that civilised law was "certain". Certainty was the hallmark of civilised law for lawyers and laymen, the difference being that to lawyers, law was clear, and to laymen it was so nebulous and difficult that they tried to avoid thinking about it altogether. It was better left to the lawyers. Clearly, neither of these approaches could work for a project that wanted to understand law in a world full of change and cultural confrontation.

\section{SOCIAL ANTHROPOLOGY}

Who else had written about African law, or better yet, had tried to understand African societies with an even wider focus? The discipline of social anthropology was relatively new when the colonial governance of African got under way. A speculative, racist and evolutionist anthropology had accompanied the European conquest of the rest of the world. In this literature, law was divided between

${ }^{5}$ The book which resulted is Law, Custom and Social Order. The colonial experience in Malawi and Zambia. Cambridge University Press, 1985 (Republished Heinemann 1998). 
primitive and civilised and it was often assumed that the existing law of non-European peoples coincided with the law of Europeans in biblical or similarly early times. Henry Maine, in a book which was a part of the legal education of many British lawyers, posited a change from Status to Contract as part of the legal evolution of the Western world. Though this formulation became an ingredient of the legal thought of the colonial world, no-one thought about the travails along the journey towards Contract.

As social anthropology took off after the First World War, it moved away, to an extent, from evolutionism. Based on Durkheimian functionalism, Bronislaw Malinowski's renowned Crime and custom in Savage Society (1926) proclaimed that law was not a matter of "codes, courts and constables", that whatever performed the function of law in "primitive" societies was law. What was law's function? It was, in his view, the settlement of disputes. Legal anthropology slid into this groove, and encouraged the metastasising of fanciful approaches about dispute settlement in socio-legal studies. But from the directions that my material pointed to this was inadequate. Both constables (in the sense of an oppressive colonial regime) and codes (furiously competing cultural ideas about what law was appropriate) were distinctly present. The apparent absence of centres of power with the ability to enforce their decisions led many anthropologists to think that there must be some other mechanism at work, mostly ignoring the fact that African powers had been destroyed by colonial conquest. Mediation; preserving social balance; restoring important relationships: all seemed to be at work. But there were also other realities which showed the need to look beyond the theory of one's discipline to the historical facts. The immediate histories of much of pre-colonial Africa had been brutal, often dominated by the slave trade and by the rule of stronger groups over weaker ones. Africans stressed their own cultures' abilities to solve disputes better and more peacefully than British legalism because they did not want to dwell on pre-colonial violence. The British stressed the value of their "rule of law" as the solution to violence. Representations of history always have a function. In this case the appeals to deep culture were ultimately about the legitimacy of the colonial enterprise.
The anthropology of the colonial era was, unsurprisingly, essentially a colonial discipline. Its subjects of research were simultaneously subjects of Empire. Colonial governments funded anthropologists because they were looking for help in understanding how to govern African subjects. This is not a criticism of the many talented people who wrote about African societies, it is simply a reflection of the world in which they lived. Overall their project failed because it was a discipline not attuned to historical change. And, most especially in the area of law, it misrepresented the processes that anthropologists were observing. Taking the observed behaviour as customs representing cultures, they failed to place it within the context of the extraordinary wrenching, by force, of African life into market economies. Once this historical context is understood, what Africans had to say about customs can be seen to be their responses to the current pressures in a new world, not a recounting of the ways of an old one.

Any research, including research about customary law and colonialism, does not take place in a vacuum. The overarching concerns of the politics of the time influence the ways in which social and economic theorists portray the world, and both have a bearing on the asking and answering of research questions. The time at which I was writing was at the end of the first decade of the decolonisation of Africa. Optimism was high. The inheritors of the newly independent states appeared to be popular and legitimate. Their aims, to unify and develop their new countries economically, were tasks that were not only political, but were embraced and theorised by the academic world. All of these countries had a dual inheritance of European and African law. How these were to be brought together, and what the future of "customary law" could be in a modern economy, were questions crucial to the implementation of economic development. So, an inquiry into law in Africa, both imported and indigenous, was far from arcane. My study was to turn out to be controversial because it not only undermined the colonial pretext that it had brought a functioning "modern" law to Africa, but much more so because it undermined the view that what was passing for "African" law at the time of decolonisation was an essentialist cultural product of Africans, "half as old as time". Many African lawyers at this time were of the view that the dual legal systems must be merged if 
the overall goal of development was to be reached, and that African law would be the basis of that merger. But how had this African law come into being? In my account it was the product of intense economic changes. These produced defensive actions by men and elders in African societies as their social power over young men and women, who could now be cash earners, was waning. Money also created new powers, among them the ability to buy land from the economically stressed, and this challenged basic African ideas about land rights. Customary law, in other words, was colonial.

\section{AFRICAN CUSTOMARY LAW AND THE NATION STATE}

Any empirical study laces one into the complicated worlds of other histories and of "theory" that are implicated within it. A study of the representations made by Africans of the worlds of the "customary", led me inevitably into the literatures of cultural creation and cultural heritage. In the post-colonial period in Africa, discourses about African culture were preeminent, a far from surprising development after centuries of scorn. Unfortunately, despotic African politicians used the cultural arguments to deny the applicability of the universality of human rights to Africa, and to oppose the inclusion of bills of right in African constitutions. Culture had become a weapon in the hands of rulers rather than ruled. I found the literature on advertising (the most pervasive public communication in the capitalist world) to be highly suggestive as a guide to the ways in which culture was being created and represented. ${ }^{6}$ As a result I was the first (I claim) to use the term "cultural branding" to describe the ways in which cultures were being created, represented and promoted. This interest led me to write about what I still think have been the misplaced but largely successful efforts to copyright heritage and "traditional knowledge". The role of law in these fields seemed to me to be most problematic. $^{8}$

Anthropology has always seemed to me to be the most vital of disciplines. ${ }^{9}$ It is the quintessential discipline of the study of globalisation, though more than often ignored by economists and others. Freeing itself slowly from its dubious beginnings as a way of theorising why some races and cultures were superior to others, it became the locus of enquiry into cultural expression and difference, a discipline which validated what had been scorned. The transformative power of western rule and capitalism has meant that anthropology now must study not original "cultures" but responsive and interrelated understandings. That it should have been vital to my studies of the worlds of the "customary" in law is clear, but I also found myself reading the literature of the anthropology of art in relation to my "heritage" work. From my work on cultural heritage, I was drawn towards the position that the greater the expressions of cultural essentialism, the more they masked resistances to changes which could not ultimately be resisted.

On a private visit to South Africa in the last years of the apartheid regime, I had a series of conversations with a friend who was to become the first head of the postapartheid regime's Constitutional Court. As we ranged over the nature of South Africa's legal system, he became increasingly alarmed. "If those are your views", he said, "you must write a book about it." I thought I had put South Africa behind me. But I embarked on a project which was to take over ten years. ${ }^{10}$ The extraordinary changes that took place in South Africa over the years in which I was researching and writing the book underlined once more the connections between the writing of an apparent account of the "past" and events in the "present". When I had begun the inquiry, in circumstances in which many

\footnotetext{
${ }^{6}$ A research journey also involves roads not taken. I now think that, if I had my time over again, I would have studied advertising which, like law, is a discourse of misleading.

${ }^{7}$ See "Human Rights and Cultural Branding: Who Speaks and How", in A An-Na'im (ed.). 2002. Cultural Transformation and Human Rights in Africa, London: Zed Books; "Branding identity and copyrighting culture: orientations towards the customary in traditional knowledge discourse", in C. Antons (ed.) 2009. Traditional Knowledge, Traditional Cultural Expressions and Intellectual Property Law in the Asia-Pacific Region. Vol. 14, Amsterdam: Kluwer Law International BV; and M. Chanock and C. Simpson (eds.). 1996. "Law and Cultural Heritage", Law in Context 14 (2).

${ }^{8}$ The push for property rights in culture and heritage has been an ultimate submission

${ }^{9}$ I was even once a Visiting Professor in Anthropology.

${ }^{10}$ It resulted in the publication of The Making of South African Legal Culture 1902-1936. Fear, Favour and Prejudice. Cambridge University Press, 2001.
} 
South African lawyers were concerned about the government's increasing contempt for "the rule of law", the prevailing puzzle seemed to be the coexistences of liberal legal forms in a racially oppressive state. By the time I approached the book's end the major concern was how to reconstruct the new state on the basis of a human rights based legal order. A legal history could clearly no longer be predominantly about the formation of two systems of "private law" for whites and Africans, but came instead to be seen through the focus of state construction. In the formation of the South African state in the early decades of the 20th century, the drive at the centre was the establishing of authority and law encompassing all aspects of society. New Statute law, usually based on models found elsewhere in the British Empire, dominated. A determined bureaucracy was the author of the legal enterprise and its main user. From their perspective judges, courts and lawyers were mere irritants, rather than the core of the developing legal order. Law was needed not to limit power, but to create it, and to channel the ways the bureaucracy used its powers, not to protect the rights of citizens.

This led me to think differently about some core beliefs of the law and society enterprise. Law's own version of itself was of a body of doctrine, often validated by a long historical continuity, and applied without reference to persons or politics. Many socio-legal scholars discovered the so-called "gap" between law in the books and law in practice. Law consequently was seen as a sort of deceptive ideology that betrayed its offers of justice in practice. But it became clear to me that law was less about limiting power than it was about increasing and endowing it. Law justified acts of violence and allocated resources. But to understand how it did this, one had to focus on all of the complex discourses around law in a society. Law, Custom and Social Order had already shown how limited it is to think about law as just "rules" applied. How then to think about it? Law and society studies correctly placed it "in context". Some emphasised society and economy underlying legal doctrine and practice. But there is also a discursive context. Lawyers' legal discourse is but a part of an interrelated set of discourses about law - bureaucratic, radical, religious. ${ }^{11}$

\section{AFRICAN CONSTITUTIONALISM}

The final steps in my research journey went back to Africa, but in a wider global context. I am writing about constitutionalism in Africa. In many ways it is a project which is prima facie absurd. African polities are marked by an absence of attachment to constitutional principles or practices. But this is not research about an absence. Both my study of colonialism and law in Central Africa, and of state building and law in South Africa, had essentially been about legal colonialism. The development of a global form of Constitution is another, and very ambitious, form of colonising by law. Constitutionalising has become a worldwide process, driven by the West, to impose a particular form of government on nation states, one which very severely limits their ability to restrict or restrain a global capitalism. The languages of democracy and human rights, in themselves profoundly attractive, are hardened into institutional forms, which are limited in variation. People around the world, endowed with Bills of Rights, are becoming "prisoners of freedom".12 Africa's continuing struggles with constitutionalism need to be seen in this light. As a historian, with my faith that putting one thing after another in chronological order would explain all, ${ }^{13}$ I embarked on a history starting with the decolonisation process which produced independent Africa's first constitutional endowment. The constitutional inheritance of British Africa was hampered by a combination of official ignorance and the meagre nature of common law constitutional thought, and the lack of intention to adhere to constitutional practice among African politicians. The collapse into varying forms of authoritarianism in well known. But the reaction to these periods is interesting. All types of

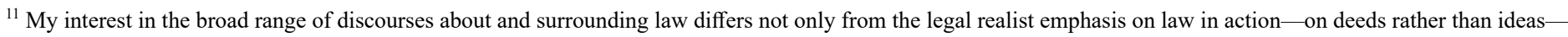
but is very different from the emerging study of the contemporary practices of the automation of legal decision-making.

12 See e.g. Harri Englund. 2016. Prisoners of Freedom: human rights and the African poor. University of California Press.

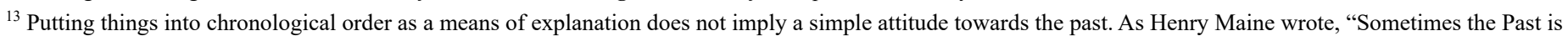

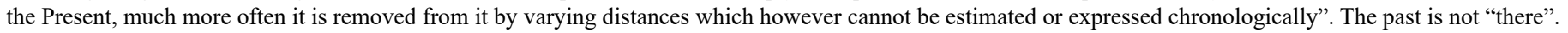

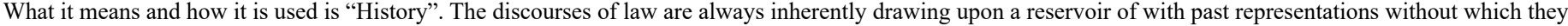
have little authority. Various pasts are therefore always present in the Present. They cannot go away, for they are the sources of legitimacy and meaning.
} 
government require a structural form. African democrats and socialists, in pursuit of their promised land of socialist development, produced one-party constitutions. African soldiers dabbled with military constitutions. These need to be understood as serious efforts in constitution making, even if they do not conform with western liberal models. Democratic change came, and often went. The bureaucratic nature of state-led development undermined the rule of law. Weak judiciaries, operating within the common law mode, declined interference in politics. The search for democratic forms of government in states manufactured by colonialism, continues. What "one thing after another" can show is a continuing struggle. The project as a whole critiques, through the lens of this African story, the ideas behind the current neo-capitalist florescence of interest in constitutionalism as a mode of governance, and the uses made of its language, especially the language of human rights. The Bill of Rights is considered as an iconic instrument that constitutionalises liberal individualism into state form. The project is linked to other parts of the journey. The work on customary law underlines for me how important it is that the basic common law of any country must be the real source of rights and a rule of law, and that it must be a common law that is an inherent part of that country's culture. Africa's constitutional weaknesses appear to have been less because of failures at the top of the legal structure, but because there was no underlying common law with which Africans identify.

But on re-visiting my scholarly production I am impressed (and relieved) by how radically political it was. And this was the primary way in which it was received. Law, Custom and Social Order, which demonstrated that African customary law was not a form of "pre-law" existing in the minds of old men, but a constantly re-created adaptation to change, was a profound challenge to the prevailing official positions. ${ }^{14}$ The legal policy makers of Africa's new states initially thought they could simply pick up the late colonial project of codifying custom from the minds of vanishing old men, and relegate it to a position inferior to imported law. But the insistent lesson of the book had been a refutation of the idea that customary law was an early form that came before civilised Western law. In its place, it demonstrated that Western law came first, that it had created customary law. The book and the subsequent articles on property law created the necessary groundwork for a legal politics which could look towards the use of African customary law as the common law of modern states, instead of as an antique survival. It was also a frontal attack on the notion that law is made up of "rules" being "applied". ${ }^{15}$ In place of this certainty, it portrayed the constant incursions into rule formations, and applications, of conflicts over economy, gender and generation. The book also had its largest impact in the area of gender. Its portrayal, in considerable detail, of the process through which African men, and their colonial rulers, contrived together to reduce the legal position of women in marriage, and to nullify their rights to land, led to my being labelled an "honorary African feminist". ${ }^{16}$

The South African book traced the fundamental influence of race in the legal system, specifically attacking the idea that the Roman-Dutch law was untainted by racism, and could simply continue as the basis of the legal system of a new state. A quaint notion persisted, and continues to persist, that somehow there was good in South Africa's legal past just because it was legal, that governments and judges adhered to a "rule of law". But the book shows, I hope, that adhering to a rule of law is not in itself a way of protecting people from the power of the state. Any state requires law, to endow its officials with power, and to the control the ways in which they use it. The post-apartheid constitution enacted an elaborate state-of-the-art Bill of Rights. ${ }^{17}$ Its new Constitutional Court has delivered inspiring judgements. But a vigorous rights discourse is evidence of the prevalence of wrongs and these wrongs are producing cynicism towards rights-based legal solutions. South Africa remains caught in a tight web of international

\footnotetext{
${ }^{14}$ So much so that the leading expert on African law in London not only refused to attend a seminar I gave but sent a long-written denunciation that he insisted be read out before I had spoken.

${ }^{15}$ Perhaps I was unconsciously influenced by being told by the senior partner of a solicitor's firm I clerked in that his philosophy was first of all to keep the client out of court. "Remember" he said "that exactly $50 \%$ of litigants with a strong case and the best counsel lose".

${ }^{16}$ See S. Ellmann, H. Klug and P. Andrews (eds.). 2010. For Martin Chanock. Essays on Law and Society. Law in Context 28 (2). The expression was used in the title of Fareda Banda's contribution to this special issue.

${ }^{17}$ A necessary assurance to both white South Africans and international capital.
} 
agreements and conventions which make up the textual universe of a new legal positivism. The scope for local solutions is narrow. The issues raised in the last chapter of the The Making of South African Legal Culture remain. Its gloomy prediction that state incapacity, rather than state ambition, would be the main challenge to a "rule of law" has come to be.

For a long period of my academic life I saw myself as a "law and society" scholar. But what did that mean to me? I wrote the series description for Cambridge Studies in Law and Society. ${ }^{18}$ It aims to publish

...work on legal discourse and practice in its social and institutional settings combining theoretical insights and empirical research...The books consider all forms of legal discourse across societies, rather than being limited to legal discourses alone.

Many valuable books have subsequently been published but, while I had insisted in my South African book that one had to consider all of societies' discourses about law in an effort to dethrone legal formalism, I found that towards the end of my association with the series I was regretting that so few of our prospective authors were interested in legal discourse itself. It seemed to me a fault in the Law and Society movement as a whole that it showed increasingly less interest in Law as a system of ideas and found it hard to escape from realist roots which often tilted towards sociological positivism. Leaving the intellectual history of law to legal scholars has been a mistake because discourse creation is, after all, a social act.

One has, I suppose, in trying to address the role of politics in one's research and writing to ask whether one is trying in each empirical work to illustrate and validate one big Truth, or whether one is simply illustrating little truths. And then there is the question of specifically relating one's academic writing to one's political activities (if any). This was not a course I took, political as I was. In the end this was largely due to the fact that I came to Australia by accident and as an émigré was not an engaged part of the society in which I lived. I remained far more engaged, as many émigrés do, by the politics of the places I had come from. Academic life itself is, of course intensely political. ${ }^{19}$ Active as I once was, fortunately it is a world remote to me now. I mention it only to underline that an academic life is inescapably political, whatever the stance of disengaged scholarship might suggest. How to sum up where the journey took me to? I contributed in a major way to the understanding of how custom works in law, in shifting the notion that it is from "time immemorial" to something that is continually freshly created. I underlined the destructive threats posed by the spread of western ideas of legalised private property. I illustrated the ways in which essentialised versions of cultures were used by the elites of the South to justify regressive law. I tried, with partial success, to demolish the narrative of the innocence of legalism in the construction of South Africa's racist state. And I am trying to question the assumption of the virtues of the global constitutional project and the particular institutionalised forms of "human rights", as they trap states and peoples in inappropriate state structures. All of the journey's ends are illustrative of the histories of the imprisonment of the peoples of the global South within the enclosure of capitalism, and their reactions to these processes. But one only tends to see these themes in one's writing after it is done. Writing history is rather like Napoleon's legendary description of the tactical secret behind his astonishing military victories: "On s'engage, et puis, on voit" ${ }^{20}$

\footnotetext{
${ }^{18}$ It is one of the best products of the School of Law and Legal Studies at Latrobe. The other founding editors were Chris Arup and Pat O'Malley. We were subsequently joined by Sally Merry and Susan Silbey.

${ }^{19}$ Henry Kissinger, an academic who later became US Secretary of State, famously remarked that academic politics were so violent "because the stakes are so small".

${ }^{20}$ One engages, and then, one sees.
} 